\title{
ENSO Impacts on Lomas Formation in South Coastal Peru: Implications for the Pliocene?
}

\author{
Timothy Paul Eichler and Ana C. Londoño \\ Department of Earth and Atmospheric Sciences, Saint Louis University, 3642 Lindell Boulevard, O’Neil Hall 205, \\ St. Louis, MO 63108, USA \\ Correspondence should be addressed to Timothy Paul Eichler; teichler@slu.edu
}

Received 21 August 2013; Accepted 13 October 2013

Academic Editor: Qi Hu

Copyright (c) 2013 T. P. Eichler and A. C. Londoño. This is an open access article distributed under the Creative Commons Attribution License, which permits unrestricted use, distribution, and reproduction in any medium, provided the original work is properly cited.

\begin{abstract}
Lomas formations in southern Peru are related to moisture availability due to frequent incursions of fog in austral winter. Due to warming of coastal waters of southern Peru during El Niño, lomas formations are enhanced via greater moisture availability for fog and drizzle. Our study evaluates the modern climatological record in austral winter to determine if there are differences in moisture availability between El Niño and La Niña for fog formation. Our results show anomalous northwesterly onshore flow, warmer than normal sea-surface temperatures, and an increase in precipitable water in El Niño, favoring lomas formations due to advection fog with higher moisture content. On the other hand, La Niña also favors frequent advection fog, with less moisture content due to strong onshore flow over relatively cool SSTs. Since lomas may represent fragments of a continuous vegetation belt that existed during the Pliocene, a permanent El Niño favoring vigorous vegetation production along the south Peruvian coast due to incursions of fog with high precipitable water may have occurred in this period. However, the possibility of normal El Niño variability superimposed on a warmer climatology producing fog with higher moisture content in both El Niño and La Niña conditions cannot be discounted.
\end{abstract}

\section{Introduction}

An aspect of the local climate in the arid, coastal regions of southern Peru is the appearance of vegetation oasis areas known as lomas [1-3]. The modern-day existence of lomas may represent remnants of a continuous vegetation belt along the coast of South America during the Pliocene (e.g., [4]). The existence of lomas is tied to advective fog from the South Pacific [5]. An increase in vegetation in lomas areas may be related to greater water availability for fog during El Niño (e.g., [6, 7]). Paradoxically, Manrique et al. [7] indicate that despite a lower frequency of fog during El Niño, a greater amount of fog and water collection occurred over southern Peru and northern Chile during the 1997-1998 El Niño [8]. Manrique et al. [7] further state that it was not possible to separate increases in water content due to austral summer drizzle from austral winter fog. However, Manrique et al. [7] suggest that El Niño induced precipitation increases in austral summer may be a short-term response. Therefore, long-term climate response of lomas formation due to El Niño may be due to greater moisture availability from fog advecting from warmer sea-surface temperature (SST) windward of the coast of southern Peru.

Given the potential linkage of enhanced lomas formation to El Niño, it is interesting to explore its existence during the early to mid-Pliocene. As discussed by Molnar and Cane [9], Ravelo et al. [4], Ravelo et al. [10], Lawrence et al. [11], and Fedorov et al. [12], the equatorial eastern Pacific was much warmer in the Pliocene period from 3 to $4 \mathrm{MA}$ years ago than today, implying a permanent El Niño state. In contrast, Watanabe et al. [13] used $\delta^{18} \mathrm{O}$ records to show that El Niño variability was unchanged during the Pliocene relative to the modern record. However, Ravelo et al. [4] and Zhang et al. [14] indicate that more data is needed to further explore El Niño variability during the Pliocene. Regardless of whether a permanent El Niño or modern-day El Niño variability superimposed on a warmer climate was operative during the Pliocene, the end result would likely have been a greater formation of lomas vegetation due to 

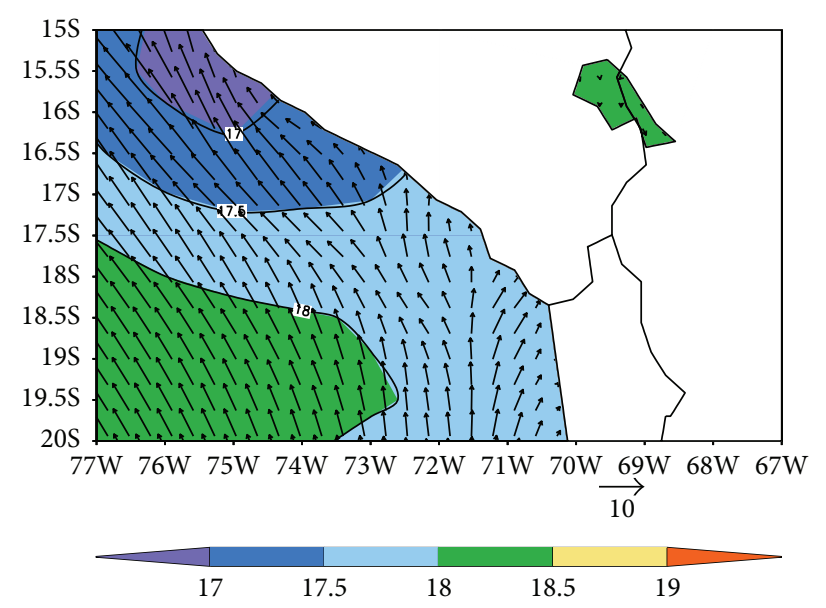

(a)

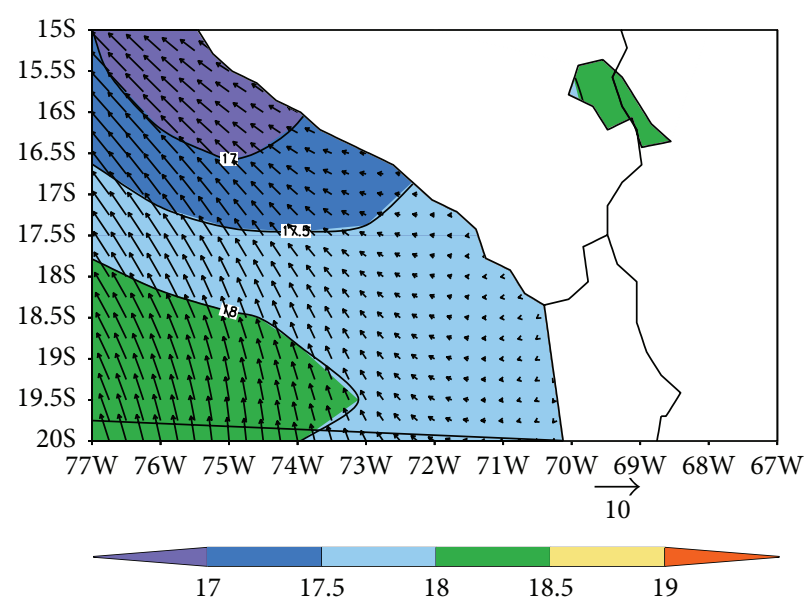

(b)

FIGURE 1: JJA climatology SST shaded (units: degrees C) surface wind vector (units: $\mathrm{m} / \mathrm{s}$ ) for (a) NOAA OI SST and CFS reanalysis surface wind (b) like (a), except using NOAA’s blended sea-wind dataset.

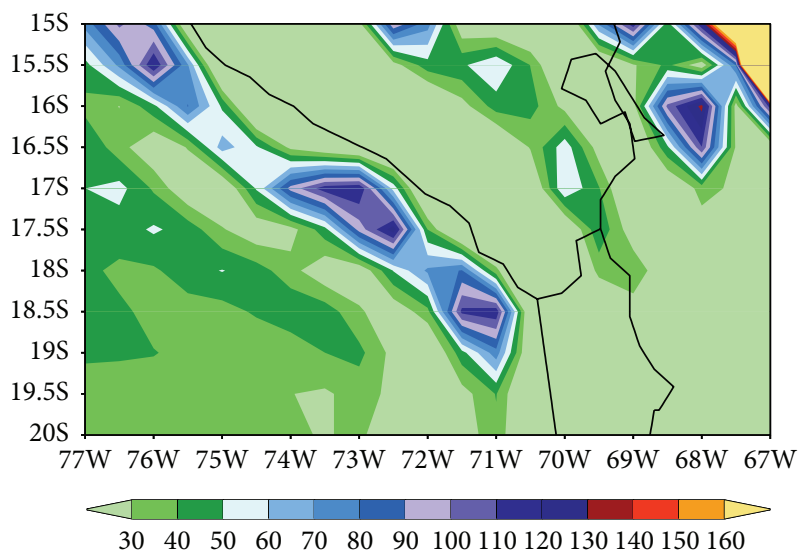

Figure 2: JJA CFS reanalysis climatology 1979-2009 precipitation shaded (units: $\mathrm{mm} / \mathrm{season}$ ).

greater moisture availability from warmer SSTs. Although other studies focus on the impacts of El Niño on South America during austral Summer (e.g., [15-17]), we analyze TRMM wind data, SST from NOAA Optimum Interpolation (OI) Sea-Surface Temperature (SST), and CFS reanalysis data for austral winter defined as June through August (JJA) to assess the potential impacts of ENSO during the period of climatological maximum for fog formation.

Because fog plays a dominant role in the climatology of coastal, southern Peru, we explore the role that El Niño plays in modulating fog production along the south Peruvian coast. Specifically, we assess if (1) El Niño produces fog containing higher precipitable water due to warmer SST and (2) El Niño induced wind circulation is favorable to advect this fog into the coastal regions. If both of these conditions are satisfied, it is possible that fog played a role in sustaining vegetation in southern coastal Peru during the Pliocene.

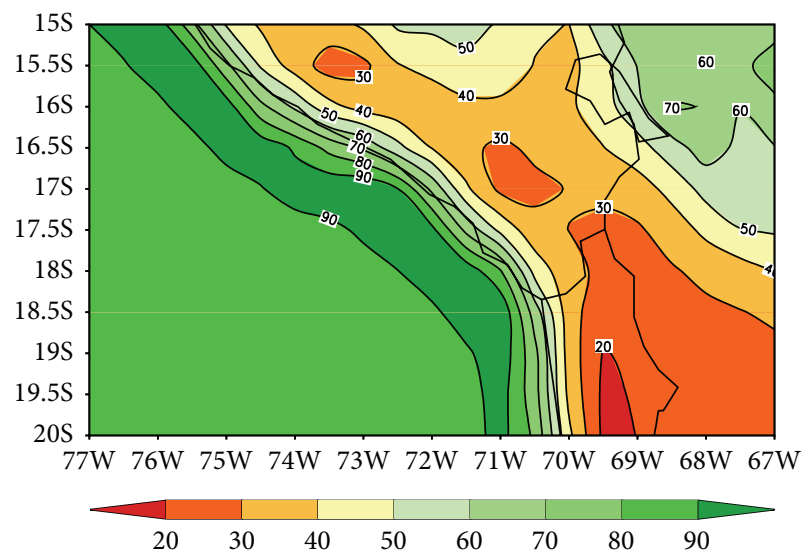

FIGURE 3: JJA CFS reanalysis climatology 1979-2009 relative humidity shaded and contoured (units: percent).

\section{Data and Methods}

We utilize NCEP's Climate Forecast System (CFS) reanalysis dataset, which is derived from a T382 resolution version of NCEP's Climate Forecast System for the main analysis portion of our work. The CFS is a fully coupled ocean/atmosphere model consisting of the Global Forecast System (GFS) atmospheric model at a T382 horizontal resolution with 64 vertical layers coupled to the MOM4 ocean model produced by the Geophysical Fluid Dynamics Lab (GFDL) (see Saha et al. [18] for more details).

Since austral winter is the main season for fog formation, we present results for the June through August (JJA) period from 1979 through 2009. To assess fog in coastal southern Peru, we chose several diagnostics from the CFS reanalysis datasets including precipitation, surface winds, sea-surface temperature (SST), dew point, relative humidity, total cloud cover in the boundary layer, and precipitable water. We also 


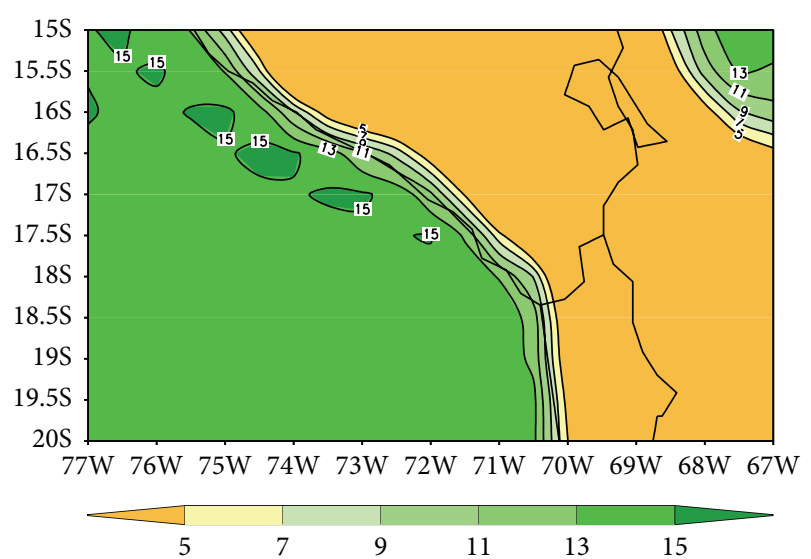

FIGURE 4: JJA CFS reanalysis climatology 1979-2009 dew point shaded and contoured (units: degrees C).

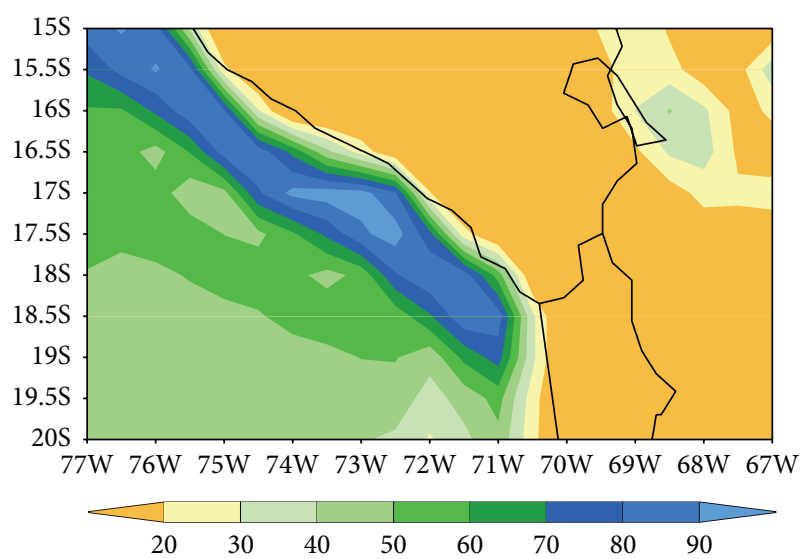

FIGURE 5: CFS reanalysis JJA climatology 1979-2009 total cloud shaded (units: percent).

analyze surface winds obtained from NOAA's blended seawind dataset from 1988 to 2009, which has a fine spatial resolution $\left(0.25^{\circ}\right.$ Lat $\times 0.25^{\circ}$ Lon $)$ and a relatively long temporal scale. For more details on this dataset, see Zhang et al. [19] and Zhang et al. [20]. For SST, we utilize NOAA Optimum Interpolation (OI) Sea Surface Temperature (SST) V2 for 1982-2009, which has a spatial resolution of $1^{\circ}$ Lat $\times 1^{\circ}$ Lon; see Reynolds et al. [21] for more details.

To explore the impacts of ENSO on the local climatology of Peru, we deploy a compositing technique to assess the effects of strong El Niño/La Niña episodes. We define warm (El Niño) and cold (La Niña) events based on the ENSO intensity scale (EIS) developed by Kousky and Higgins [22]. The EIS is a five-class intensity scale that is calculated by doubling the oceanic Niño index (ONI), defined as the 3month running mean of SST anomalies for the Niño-3.4 region. The five categories are strong El Niño, weak/moderate El Niño, neutral conditions, weak/moderate La Niña, and strong La Niña. By utilizing the EIS classification system, we can more objectively composite the strongest El Niño/La Niña events. To adjust for the seasonal cycle of ENSO, we normalize by dividing the ONI index by the JJA ONI standard

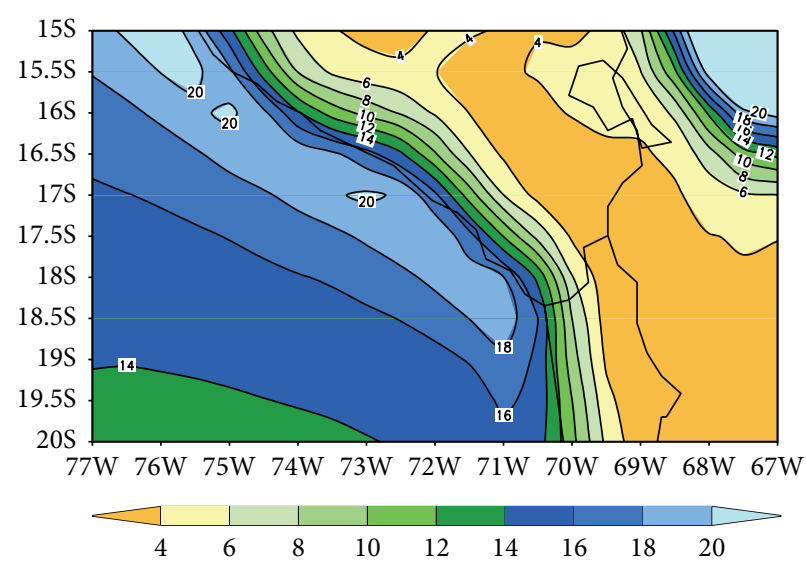

FIGURE 6: JJA CFS reanalysis climatology 1979-2009 precipitable water shaded (units: $\mathrm{mm}$ ).

TABLE 1: Years used in composite analysis for moderate to strong El Niño, moderate to strong La Niña, and neutral years. Composites based on JJA EIS values normalized by JJA standard deviation.
El Niño: $1982,1987,1991,1997,2002,2004,2009$
La Niña: 1988,1999
Neutral: $1979,1980,1983,1984,1986,1989,1990,1995,1996,2001$, 2006, 2007, 2008

deviation as suggested by Kousky and Higgins [22]. For El Niño (La Niña), we composited all moderate to strong events for JJA for EIS greater than (less than) two (minus two) from 1979 through 2009. Since ENSO peaks in northern hemisphere winter, we inspected the Climate Prediction Center (CPC) ONI website [23] to verify that the JJA seasons we chose were from El Niño/La Niña events instead of isolated positive or negative values in nonevent periods. We defined neutral years as years in which the EIS index was between plus and minus one. The years used for compositing are shown in Table 1. To aid in quantifying our results, we generated correlation maps of the EIS index with SST and precipitable water, with significance tabulated for $90 \%$ using a 2-tailed test. Performing these analyses give a good picture of how ENSO impacts winter climate in southern, coastal Peru and may provide clues on how the climate of the Pliocene affected the local area.

\section{Local Climatology}

The local climatology of southern coastal Peru in austral winter is marked by little precipitation, with frequent incursions of fog along the coast. Since the frequency of fog is linked to onshore flow, Figure 1 shows the JJA climatology of SST and surface wind for the southern Peruvian coast for CFS reanalysis and the blended sea-wind product data (Figures 1(a) and 1(b), resp.). Along the South American coastline from $30^{\circ} \mathrm{S}$ to $18^{\circ} \mathrm{S}$, we note onshore, southerly flow over cool SSTs into southern coastal Peru (Figure 1(a)). Despite the onshore flow, the winter climate is quite arid as shown by the JJA mean precipitation, with totals for the coastal areas 


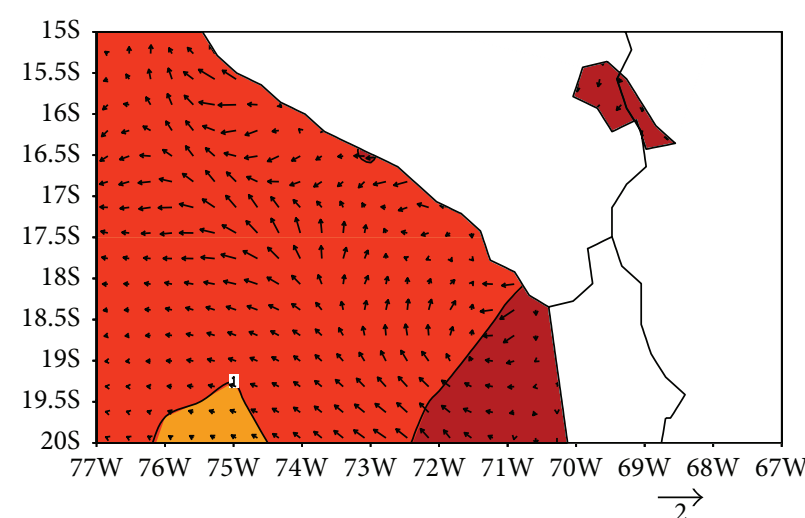

(a)

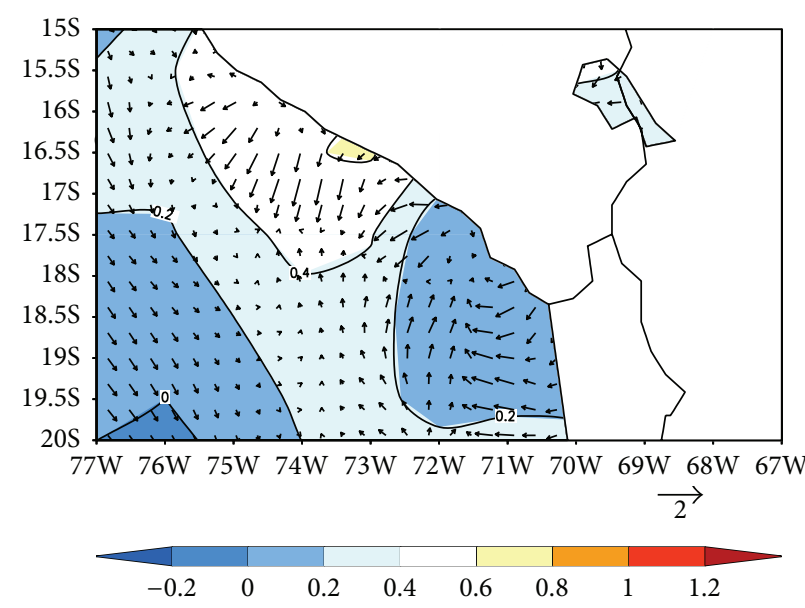

(c)

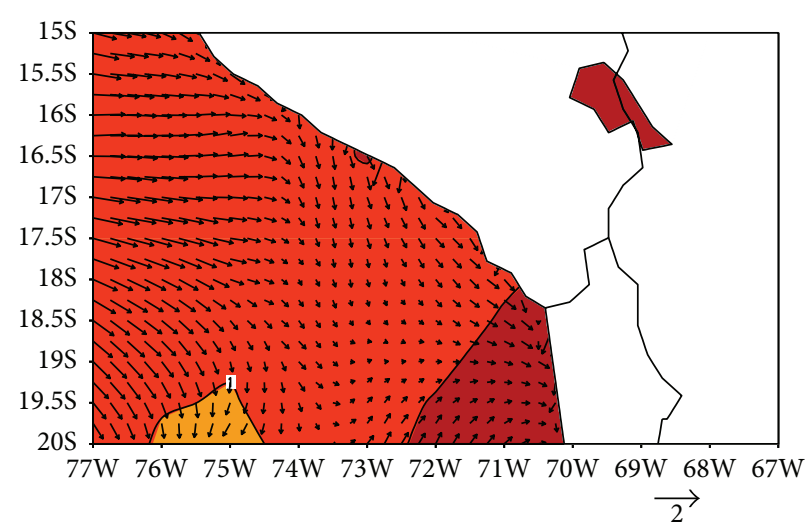

(b)

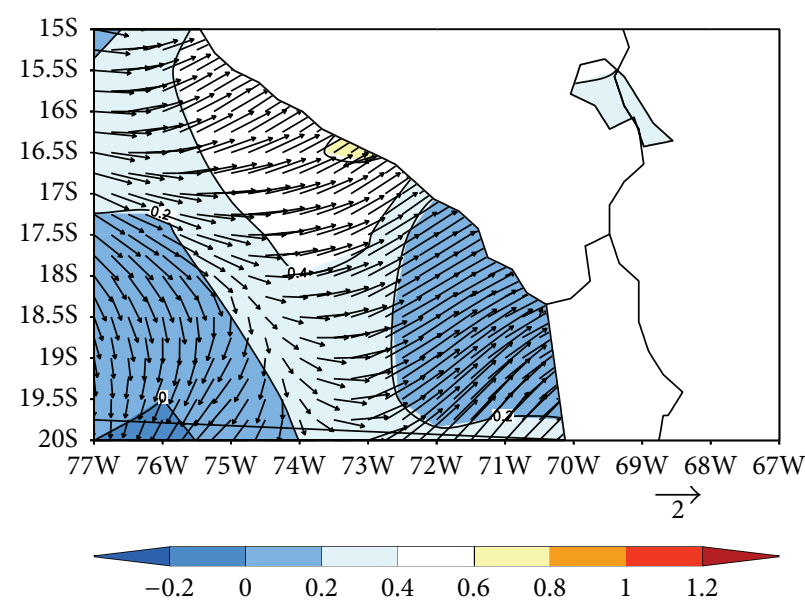

(d)

Figure 7: (a) El Niño composite (El Niño-Neutral) for (a) CFS reanalysis surface wind vector (units: standard deviation), NOAA OI SST shaded, (units: standard deviation). (b) Like (a) except for using winds from NOAA's blended sea-wind data. (c) like (a) except for La Niña. (d) Like (b) except for La Niña.

less than $30 \mathrm{~mm}$ (Figure 2). Consistent with the formation of fog, a large gradient in relative humidity (RH) is seen on the coastline, with $\mathrm{RH}$ values ranging from greater than $90 \%$ offshore to less than 30\% inland from the coast (Figure 3). Coincident with the $\mathrm{RH}$ gradient, a gradient in dew point temperature (DP) is also seen on the coast (Figure 4). The sharp dropoff in RH and DP inland from the coast is likely due to the sharp topographical barrier east of the coastline, which helps to define the local climatology of the coastal region of southern Peru.

To further examine the propensity for fog along the coast, we examined the climatology of the total cloud amount for the boundary layer (Figure 5) and precipitable water for the vertical column (Figure 6). A zone of greater than $80 \%$ cloud coverage is seen just offshore from $19^{\circ} \mathrm{S}$ to $15^{\circ} \mathrm{S}$ (Figure 5), with precipitable water values of greater than $18 \mathrm{~mm}$. Of interest is that the cloudy zone extends to the coastline, with cloud amounts of approximately $30 \%$ on the coast from $18^{\circ} \mathrm{S}$ and $17.5^{\circ} \mathrm{S}$ (Figure 5). Coinciding with the greater frequency of clouds from coastal regions from $18^{\circ} \mathrm{S}$ to $17.5^{\circ} \mathrm{S}$ relative to inland is the higher precipitable water amounts of greater than $20 \mathrm{~mm}$ (Figure 6). The picture that emerges for the climate of coastal Peru is one of extreme aridity punctuated by cool, onshore southeasterly flow impinging on the more east-west portion of the coastline from $17.5^{\circ} \mathrm{S}$ to $18^{\circ} \mathrm{S}$. Since there is a sharp topographical gradient, upsloping results in frequent fog.

\section{Interannual Variability (ENSO)}

Composite surface wind and SST are shown for El Niño relative to neutral conditions for CFS reanalysis and TRMM data (Figures 7(a) and 7(b), resp.). While SST anomalies are quite small, large differences in winds are seen, with anomalous offshore flow in the CFS reanalysis data and strong onshore winds for the TRMM data (cf. Figure 7(a) with Figure 7(b)). This is consistent with the idea that warmer air flowing over colder SST produces more frequent fog during La Niña (Manrique et al. [7]). Despite this, the anomalous onshore flow over warmer SSTs during El Niño is consistent with the increase in water that was collected in the lomas areas in southern Peru and northern Chile during the 1997/1998 


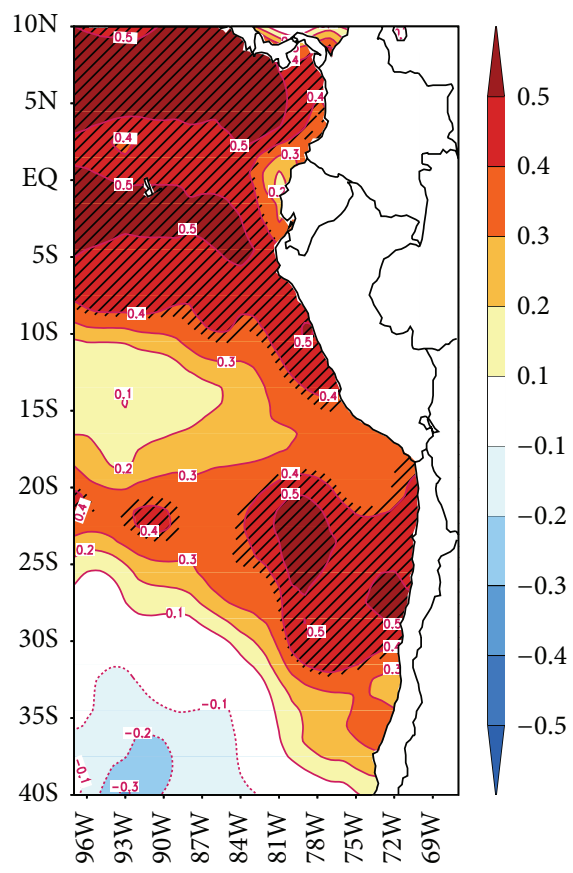

FIGURE 8: JJA correlation of EIS index with NOAA OI SST shaded and contoured (data from 1982-2009). Hatched areas are significant at $90 \%$ for a 2 -tailed test.
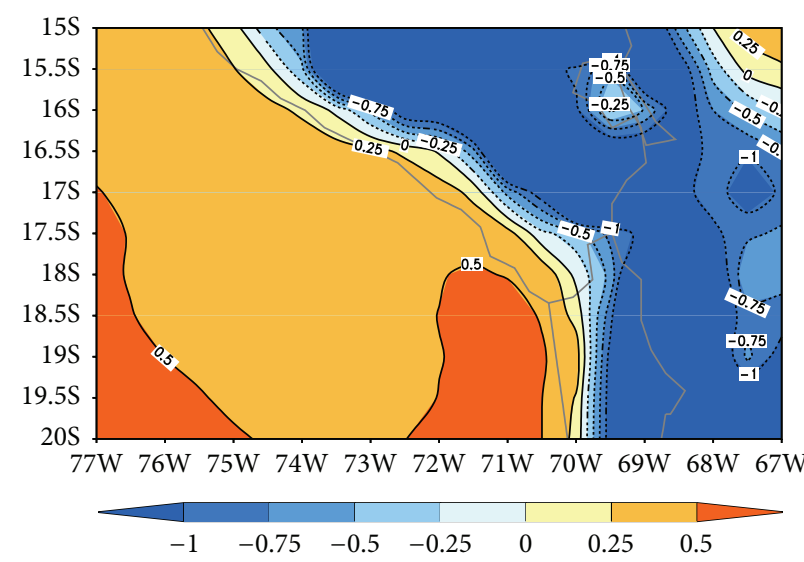

(a)

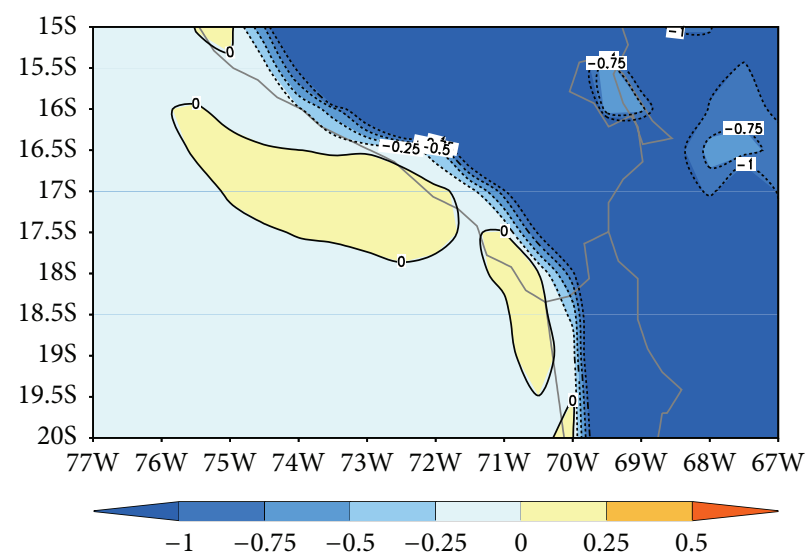

(b)

Figure 9: (a) El Niño composite (El Niño-neutral) for dew point shaded and contoured (units: standard deviation). (b) Like (a) except for La Niña composite.

El Niño [24]. The extent of anomalously warm SST down the South American coastline is shown by correlating SST with the EIS index, with significant positive correlations seen as far south as $30^{\circ} \mathrm{S}$ (Figure 8). The warmer coastal waters seen during El Niño are likely related to poleward propagating, coastally trapped kelvin waves which reduce upwelling [25]. The onshore flow blowing over warmer SSTs in El Niño is reflected by widespread, nonsignificant increases in dew point along and off the south Peruvian coast for El Niño (Figure 9(a)), with little change noted for La Niña (Figure 9(b)). The positive correlation of EIS with precipitable water in the vicinity of the southern Peru coastline is consistent with higher moisture for fog formation during El Niño (Figure 10). Coupling this with anomalous northwesterly flow over anomalously warm SSTs during El Niño suggests that frequent incursions of fog with higher precipitable water values occur during El Niño.

The implication of our results for the Pliocene period can be interpreted in two ways. First, if the Pliocene was dominated by a climatologically permanent El Niño, then it is feasible that more frequent incursions of fog with high precipitable water values helped to support the coastal vegetation in southern Peru. An alternative scenario is that if modern-day El Niño variability was superimposed on a warm climatological state as suggested by Watanabe et al. [13], then it is also possible that both El Niño and 


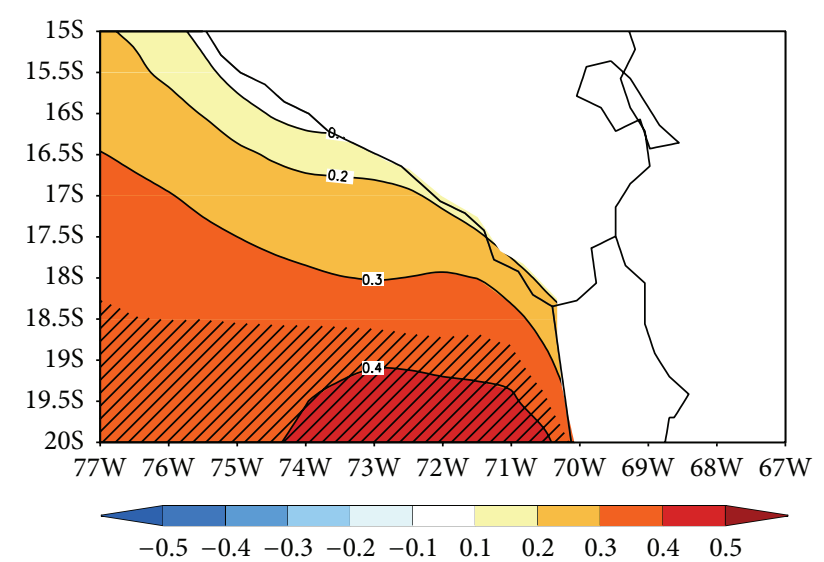

FIGURE 10: JJA correlation of EIS index with CFS reanalysis precipitable water shaded and contoured (data from 1979 to 2009). Hatched areas are significant at a $90 \%$ level for a 2-tailed test.

La Niña contributed to enhanced fog formation; the former by the aforementioned mechanism of anomalous northwesterly onshore flow over warmer SSTs, while the latter may have been operative by strong, anomalous westerly flow over climatologically warmer SST (relative to the modern record) windward of the southern Peru coastline.

\section{Conclusions}

Our results support a climatologically distinct zone along the southern Peru coastline characterized by low precipitation and large gradients in moisture as shown by RH, DP, and cloud cover. TRMM wind data supports the idea of mean inflow into the southern Peruvian coastline supporting frequent fog formation during austral winter. Despite the differences between TRMM and CFS reanalysis winds, onshore flow (climatological for CFS reanalysis and anomalous for TRMM) over anomalously warm SST supports the incursion of fog with higher moisture values during El Niño. Frequent incursions of fog are also likely due to strong onshore flow during La Niña, although colder SST relative to El Niño suggests fog with lower moisture content. The concept of fog with greater moisture content is supported to a smaller degree by nonsignificant increases in dew point along the coast during El Niño and to a larger degree by positive correlations of El Niño with precipitable water from the southern Peru coastline westward into the South Pacific. While different theories exist pertaining to the nature of El Niño during the Pliocene, fog with a greater moisture content occurring during a permanent El Niño state due to onshore flow over warm SSTs supports an increase in vegetation along the southern Peru coastline. Conversely, modern-day El Niño variability superimposed on climatologically warmer SSTs also supports greater vegetation by El Niño-induced onshore flow, as well as strong onshore flow during La Niña over warmer climatological SSTs relative to the modern record. Global climate models may help to further examine these potential mechanisms.

\section{Conflict of Interests}

Dr. Timothy Eichler and Dr. Ana Londono declare that there is no conflict of interests regarding the publication of this paper.

\section{References}

[1] M. O. Dillon, "The botanical response of the Andean desert lomas formations to the 1982-83 El Niño event," American Journal of Botany, vol. 72, p. 950, 1985, Abstract.

[2] M. O. Dillon, "The silver lining of a very dark cloud, botanical studies in coastal Peru during the 198283 El Niño event," Field Museum of Natural History Bulletin, vol. 56, pp. 6-10, 1985.

[3] M. O. Dillon, "Origins and diversity of the lomas formations in the Atacama and Peruvian deserts of western South America," American Journal of Botany, vol. 76, p. 212, 1989, Abstract.

[4] C. Ravelo, J. LaRiviere, P. Dekens, and M. Wara, "The pliocene: a permanent El Niño-like state? Yes and No," 2012, http://aos .princeton.edu/philander/presentations/panel4_ravelo.pdf.

[5] P. Cereceda, H. Larrain, P. Osses, M. Farías, and I. Egaña, "The spatial and temporal variability of fog and its relation to fog oases in the Atacama Desert, Chile," Atmospheric Research, vol. 87, no. 3-4, pp. 312-323, 2008.

[6] M. Muñoz-Schick, Z. R. . Pinto, A. Mesa, and A. Moreira, "Fog oases during the El Niño Southern Oscillation 1997-1998, in the coastal hills south of Iquique, Tarapacá region, Chile," Revista Chilena de Historia Natural, vol. 74, no. 2, pp. 389-405, 2001.

[7] R. Manrique, C. Ferrari, and G. Pezzi, "The influence of El Niño Southern Oscillation (ENSO) on fog oases along the Peruvian and Chilean coastal deserts," in Proceedings of the 5th International Conference on Fog, Fog Collection and Dew, pp. 2530, Münster, Germany, July 2010.

[8] L. Villegas, P. Jiménez, C. Talavera, and A. Ortega, "Evaluation of fog moisture absorption, in Lomas of Atiquipa (ArequipaPeru) from 2002 to 2006," in Proceedings of the 4th International Conference on Fog, Fog Collection and Dew, La Serena, Chile, July 2007 22-27.

[9] P. Molnar and M. A. Cane, "Early Pliocene (pre-Ice Age) El Niño-like global climate: which El Niño," Geosphere, vol. 3, no. 5, pp. 337-365, 2007.

[10] A. C. Ravelo, P. S. Dekens, and M. McCarthy, "Evidence for El Niño-like conditions during the Pliocene," GSA Today, vol. 16, pp. 4-11, 2006.

[11] K. T. Lawrence, Z. Liu, and T. D. Herbert, "Evolution of the eastern tropical Pacific through Plio-Pleistocene glaciation," Science, vol. 312, no. 5770, pp. 79-83, 2006.

[12] A. V. Fedorov, P. S. Dekens, M. McCarthy et al., "The pliocene paradox (mechanisms for a permanent El Niño)," Science, vol. 312, no. 5779, pp. 1485-1489, 2006.

[13] T. Watanabe, A. Suzuki, S. Minobe et al., "Permanent El Niño during the Pliocene warm period not supported by coral evidence," Nature, vol. 471, no. 7337, pp. 209-211, 2011.

[14] Z.-S. Zhang, Q. Yan, J.-Z. Su, and Y.-Q. Gao, "Has the problem of a permanent El Niño been resolved for the Mid-Pliocene?" Atmospheric and Oceanic Science Letters, vol. 5, no. 6, pp. 445448, 2012.

[15] R. D. Garreaud, M. Vuille, R. Compagnucci, and J. Marengo, "Present-day South American climate," Palaeogeography, Palaeoclimatology, Palaeoecology, vol. 281, no. 3-4, pp. 180-195, 2009. 
[16] B. Rein, "How do the 1982/83 and 1997/98 El Niños rank in a geological record from Peru?" Quaternary International, vol. 161, no. 1, pp. 56-66, 2007.

[17] M. Vuille, R. S. Bradley, and F. Keimig, "Interannual climate variability in the Central Andes and its relation to tropical Pacific and Atlantic forcing," Journal of Geophysical Research D, vol. 105, no. 10, pp. 12447-12460, 2000.

[18] S. Saha, S. Nadiga, C. Thiaw et al., "The NCEP Climate Forecast System," Journal of Climate, vol. 19, no. 15, pp. 3483-3517, 2006.

[19] H.-M. Zhang, J. J. Bates, and R. W. Reynolds, "Assessment of composite global sampling: sea surface wind speed," Geophysical Research Letters, vol. 33, no. 17, Article ID L17714, 2006.

[20] H.-M. Zhang, R. W. Reynolds, and J. J. Bates, "Blended and gridded high resolution global sea surface wind speed and climatology from multiple satellites: 1987-Present," in Proceedings of the 86th American Meteorological Society, Atlanta, Ga, USA, February 2006, Paper \#P2.23.

[21] R. W. Reynolds, N. A. Rayner, T. M. Smith, D. C. Stokes, and W. Wang, "An improved in situ and satellite SST analysis for climate," Journal of Climate, vol. 15, no. 13, pp. 1609-1625, 2002.

[22] V. E. Kousky and R. W. Higgins, "An alert classification system for monitoring and assessing the ENSO cycle," Weather and Forecasting, vol. 22, no. 2, pp. 353-371, 2007.

[23] ONI, http://www.cpc.ncep.noaa.gov/products/analysis_monitoring/ensostuff/ensoyears.shtml.

[24] P. Jimenez et al., "Meteorological conditions in the Lomas de Mejia during 1997-98 El Niño and its influence on vegetation," Peruvian Journal of Biology, pp. 133-136, 1999.

[25] S. Hormazabal, G. Shaffer, and O. Pizarro, "Tropical Pacific control of intraseasonal oscillations off Chile by way of oceanic and atmospheric pathways," Geophysical Research Letters, vol. 29, no. 6, pp. 5-1-554, 2002. 

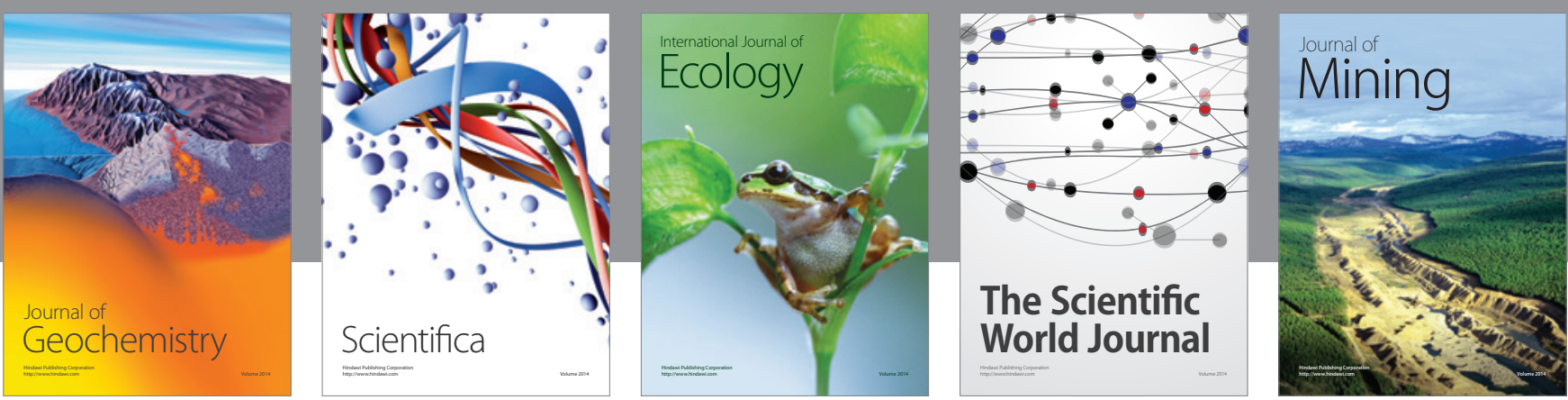

The Scientific World Journal
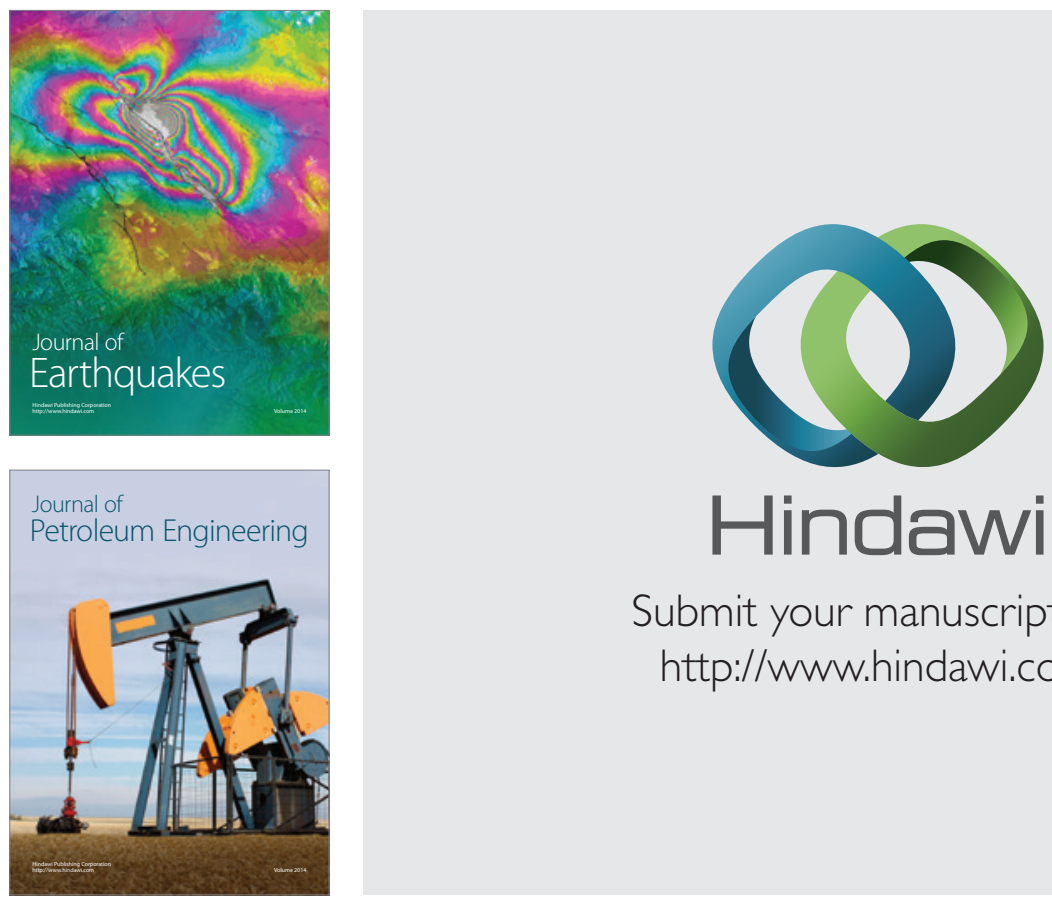

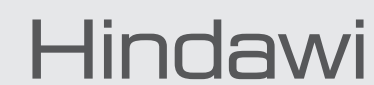

Submit your manuscripts at

http://www.hindawi.com
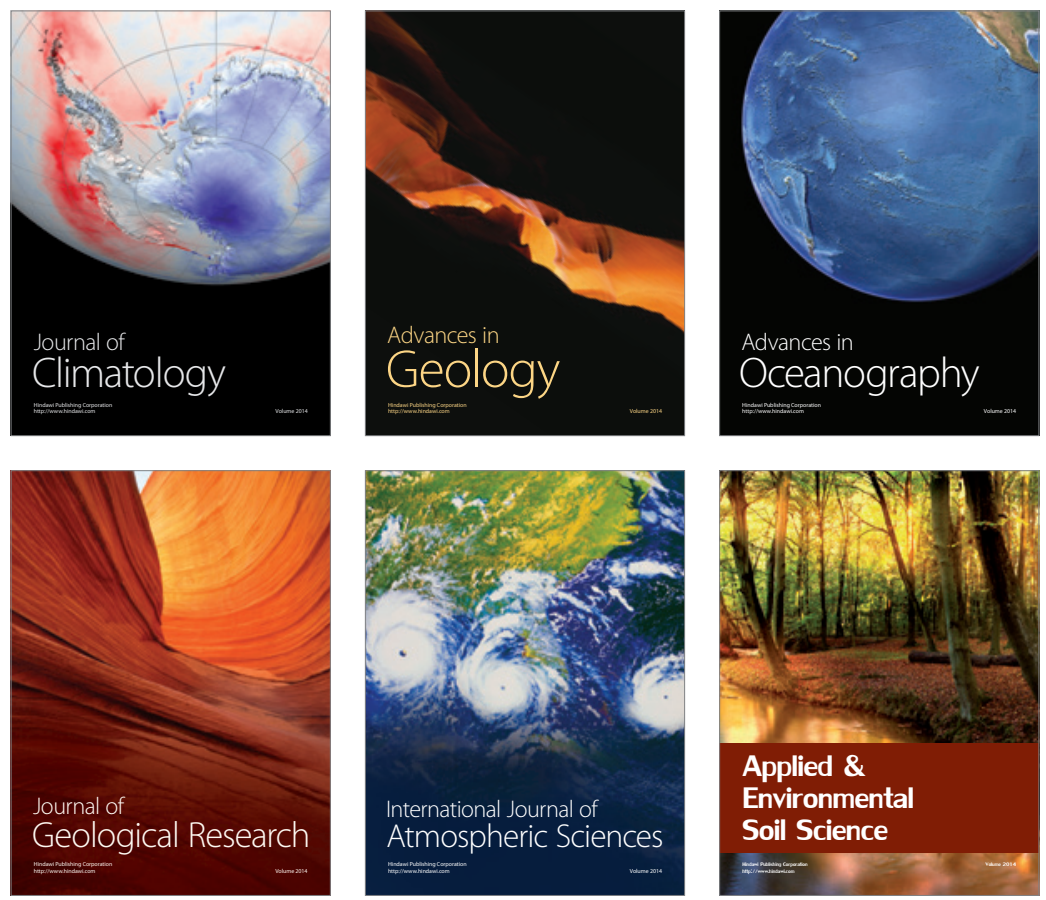
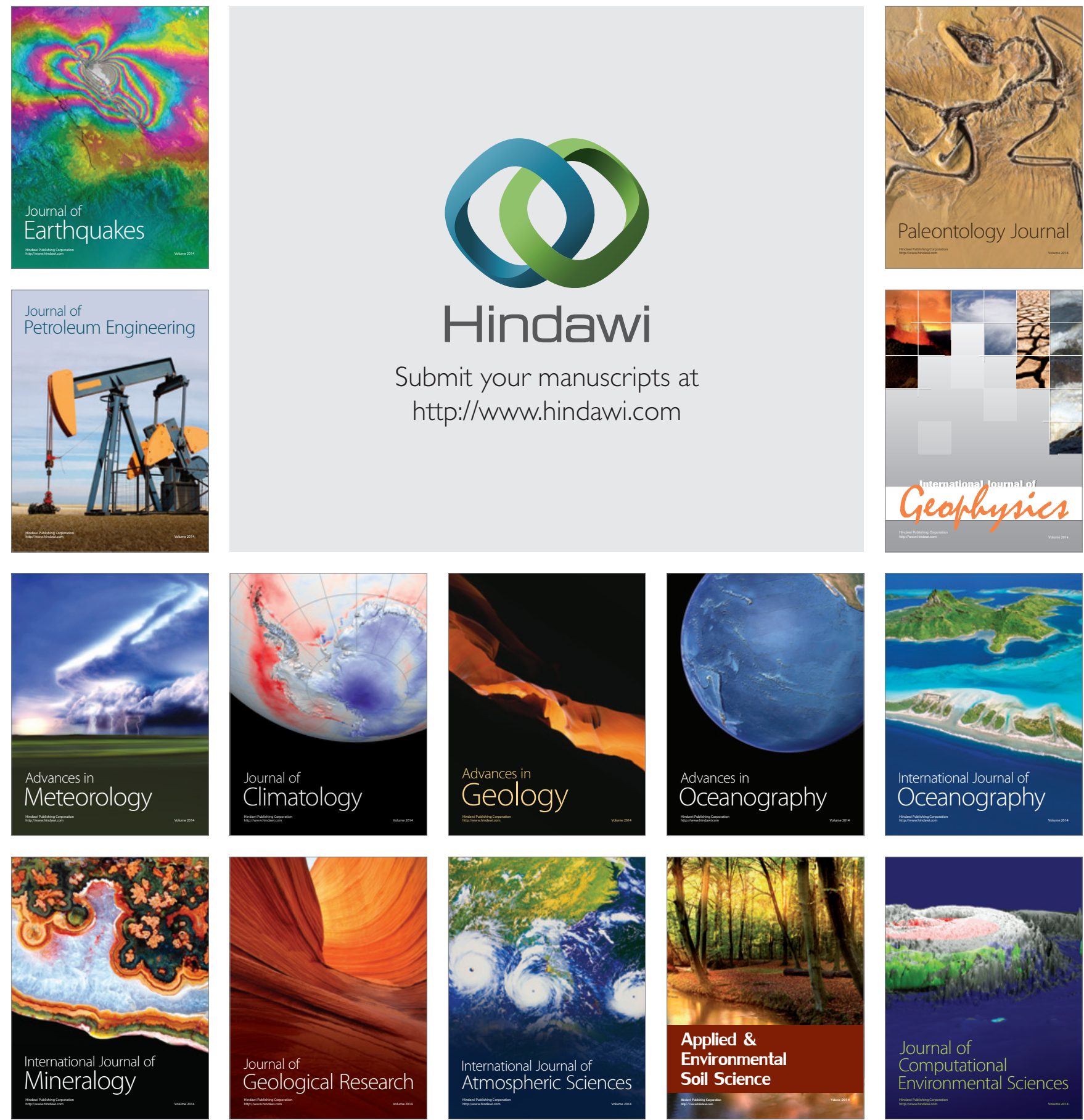